\title{
DESAIN KURIKULUM PENDIDIKAN ISLAM DI SMA (Membumikan Wacana Kurikulum Berbasis Tauhid Sosial)
}

\section{Muchamad Agus Munir*}

\begin{abstract}
Abstrak: artikel ini bertujuan untuk menguraikan desain kurikulum pendidikan Islam di sekolah umum, khususnya SMA. Permasalahan kurikulum pendidikan Islam yang terjadi selama ini di sekolah-sekolah umum terletak pada porsi materi yang hanya sebatas pengetahuan, sehingga tidak banyak menyentuh realitas sosial. Untuk itu perlu adanya desain dalam kurikulum pendidikan Islam. Salah satu yang menjadi tawaran adalah membumikan kurikulum berbasis tauhid sosial. Hasil temuan ini adalah, bahwa tauhid sosial sendiri dapat diartikan sebagai bentuk kesadaran umat Islam yang dilandasi dengan nilai-nilai ketuhanan dan akidah dalam berkiprah di dalam realitas sosial. Kurikulum tauhid sosial di SMA kiranya sebagai kesadaran ummat Islam yang dilandasi ketauhidan dalam membentuk kehidupan di dalam dunia sosial. Isinya tidak hanya mencakup nilai-nilai tauhid semata, melainkan problem-problem yang terjadi dalam realitas sekarang.
\end{abstract}

Kata Kunci: desain kurikulum, pendidikan Islam, SMA, tauhid sosial.

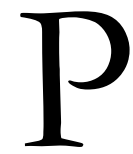

ersoalan kurikulum pendidikan Islam di sekolah selama ini belum fungsional. Artinya peserta didik memang sudah belajar tentang materi-materi pendidikan Islam, tetapi masih banyak perilaku-perilaku yang tidak sesuai dengan ajaran Islam. Ketidaksesuaian itu diasumsikan karena di dalam kurikulum itu tidak dimasukkan tentang nilai-nilai tauhid sosial. Tetapi yang diajarkan hanyalah pengetahuan yang sifatnya normatif. Padahal, Pendidikan Islam adalah pendidikan dengan melalui ajaran-ajaran

Akademisi Pendidikan Islam, Alumnus Pascasarjana UIN Sunan Kalijaga Yogyakarta. Aktif diberbagai forum kajian pendidikan dan lembaga penelitian Pendidikan Islam. Email: siapamirat@gmail.com 
agama Islam, yaitu berupa bimbingan dan asuhan terhadap anak didik agar nantinya setelah selesai dari pendidikan ia dapat memahami, menghayati, dan mengamalkan ajaran-ajaran agama Islam yang telah diyakininya secara menyeluruh, serta menjadikan ajaran agama Islam itu sebagai suatu pandangan hidupnya demi keselamatan dan kesejahteraan hidup di dunia maupun di akhirat kelak (Daradjat, dkk. 2011, 86). Agama Islam mengatur hubungan manusia dengan Tuhannya, manusia dengan manusia, dan manusia dengan alam sekitarnya yang menyangkut bidang aqidah, syariah, dan akhlak. Sehingga dalam pelaksanaan pendidikan tidak terlepas dari pemahaman antara dimensi ketuhanan yang termanifestasikan dalam akidah, serta dimensi sosial yang termanifestasi dari mu'amalah (Ahmadi dan Uhbiyati 2001, 109).

Lebih jauh lagi pola pengajaran materi pendidikan Islam di SMA yang masuk mata pelajaran Pendidikan Islam, hanya sebatas pengetahuan. Mereka menguasai materi tersebut dengan maksimal, contohnya peserta didik SMA mengerti akan cara-cara menunaikan rukun Islam, mengetahui akhlak yang terpuji dan tercela, mengetahui konsep tentang tauhid, dan sebagainya. Namun hal itu belum mampu menjangkau dimensi aplikatif, sehingga pengetahuan yang dikuasai oleh peserta didik yang ada di SMA hanya sebatas pegetahuan saja.

Dalam praktiknya, perilaku keagamaan yang ditampilkan oleh peserta didik di sekolah terutama sekolah SMA, tidak optimal. Sebab, pengajaran dan pembelajaran pendidikan Islam hanya sebatas konsep dan teori. Jadi, peserta didik tidak terlalu merasa penting untuk menerapkan perilaku keagamaan seoptimal mungkin. Mereka mengaanggap bahwa pendidikan Islam hanya sebatas ritualistik, seperti shalat, zakat, puasa, dan sebagainya. Padahal secara garis besar pendidikan Islam melebihi hal itu. Lebih lanjut salah satu kendalanya adalah terbatasnya jam pelajaran agama. Guru Besar Universitas Pendidikan Indonesia (UPI), yang juga mantan Direktur Jendral Dirjen Pendidikan Islam Kementerian Agama (Dirjen Pendis) Mohammad Ali MA, dalam makalahnya berjudul "Pegembangan Agama Islam di Sekolah" mengatakan, 
penyelenggaraan pendidikan Islam di sekolah penuh tantangan, karena secara formal penyelenggaraan pendidikan Islam di sekolah hanya 3 jam pelajaran per minggu. Jadi, apa yang bisa mereka peroleh dalam pendidikan yang hanya 3 jam pelajaran. Jika sebatas hanya memberikan pengajaran agama Islam yang lebih menekankan aspek kognitif, mungkin guru bisa melakukannya, tetapi kalau memberikan pendidikan yang meliputi tidak hanya kognitif tetapi juga sikap dan keterampilan, guru akan mengalami kesulitan (Ahmadi dan Uhbiyati 2001, 109).

Dalam realisasi sejarahnya, pengembangan kurikulum pendidikan Islam tersebut dapat dicermati dari fenomena berikut: (1) perubahan dari tekanan pada hafalan dan daya ingatan tentang teks-teks dari ajaran-ajaran agama Islam, serta disiplin mental spiritual; (2) perubahan dari cara berpikir tekstual, normatif, dan absolutis kepada cara berpikir historis, empiris, dan kontekstual; (3) perubahan dari tekanan pada produk atau hasil pemikiran keagamaan Islam dari para pendahulunya; (4) perubahan dari pola pengembangan kurikulum Pendidikan Islam yang hanya mengandalkan pada para pakar dalam memilih dan menyusun isi kurikulum Pendidikan Islam (Gunawan 2013, 23).

Rumusan kurikulum yang ada dalam pendidikan Islam seperti di atas harus selalu dikembangkan guna memberikan pemahaman dan pengetahuan kepada anak didik agar tidak lepas dari unsur-unsur tauhid. Sebab unsur tauhid membawa semangat keagamaan dan komitmen kepada agama, masyarakat dan Tuhan. Ketiga fokus kajian yang ada dalam kurikulum tersebut, senada dengan apa yang ada dalam orientasi kurikulum. Bahwa orientasi kurikulum mencakup tiga hal yaitu, orientasi pada pengembangan peserta didik, orientasi pada pengembangan sosial, dan orientasi pengembangan ilmu pengetahuan.

Namun dalam realitas sekarang ini kurikulum dalam pendidikan Islam, dalam proses belajar-mengajarnya pun masih terbatas hanya dalam tataran pengetahuan belaka, tanpa mempersoalkan realitas sosial yang up to date, sehingga banyak kekhawatiran muncul. Kekhawatiran tersebut berkaitan dengan lulusan pendidikan Islam 
sekarang hanya akan melahirkan orang yang pandai dalam agama, namun gagap dalam realitas sosial. Dalam tataran ini kiranya formulasi dari kurikulum pendidikan Islam kurang bisa menjawab perkembangan zaman, beserta piranti permasalahan yang dibawanya. Sehingga apa yang dikatakan oleh Amien Rais menjadi kenyataan, bahwa;

"Orang Islam terkungkung dalam wacana keislaman dan islamopobia, yang membawa kemunduran peserta didik Islam dalam mengarungi peradaban sekarang ini. Persoalan tersebut tidak terlepas dari kurangnya strategi dan pemberdayaan masyarakat dalam menghadapi tantangan tersebut, hal inilah yang melahirkan krisis-krisis dalam peserta didik Islam. Pertama perlu dicatat adanya moral degenaration, yang mengakibatkan ketidakjelasan batasan baik dan buruk. Kedua, adanya disparitas income antara negara yang kaya dengan negara yang miskin. Ketiga, adanya disparitas pendidikan, dalam hal ini ada negara-negara yang IPTEKnya melimpah ruah, ada pula yang tertinggal. Keempat, terjangkitnya kondisi yang hobbesian, artinya bahwa yang kuat itu memeras yang lemah. Kelima, destruksi ekologis yang sangat menyedihkan”. (Rais 1998, 99-100)

Keterkaitan hubungan antara Tuhan, manusia dan alam, harus ditegakkan agar menciptakan keharmonisan dalam kehidupan. Dengan begitu pemahaman tentang pendidikan Islam senantiasa harus berjalan dalam koridor yang peka terhadap ibadah dan sosial. Dalam konteks di Indonesia, sesungguhnya perjuangan menegakkan keadilan sosial memerlukan waktu, ketekunan, dan keberanian moral. Ini karena Indonesia termasuk yang sangat unik, dalam arti kesenjangan sosialnya itu luar biasa. Di antara negaranegara berkembang, kesenjangan sosial di Indonesia ini termasuk memecahkan rekor selain korupsi. Di sini, yang kaya itu kaya sekali, sedangkan yang miskin betul-betul berada di bawah garis kemiskinan (Ahmadi dan Uhbiyati 2001, 118).

Perlunya mempertimbangkan tauhid sosial dalam kerangka kurikulum pendidikan Islam, agar dapat menterjemahkan keyakinan peserta didik menjadi konkrit, sekaligus menjadi satu sikap budaya untuk mengembangkan amal saleh (Rais 1998, 41). Artinya, peserta didik Islam memiliki kewajiban keagamaan dalam memperjuangkan 
masa depan yang lebih bagus, dengan menyertakan keharusan tegaknya tauhid sosial.

Dalam kaitannya dengan tauhid dan pembangunan peserta didik yang penting adalah kita perlu mempertajam kesadaran sejarah kita agar kita tidak mengulangi lagi kesalahan-kesalahan di masa lampau dan janganlah sampai kita menanduk batu untuk kedua kalinya (Ahmadi dan Uhbiyati 2001, 213). Allah berfirman, "Wabai orangorang yang beriman, hendaklah engkau melihat masa lalumu, apa yang telah engkau capai dan engkau lakukan. Yang salab dan benar di hari-hari kemarin sebagai bekal untuk menyongsong masa depan yang penub tantangan. Penajaman-penajaman pemahaman tauhid harus terus kita lakukan karena pemahaman tauhid yang tumpul, yang statis, dan klise-lah yang merupakan sumber awal dekadensi dan degenerasi peserta didik. Kalau kita tidak paham tauhid, kita akan melihat kelompok kita sudah the best, lalu tidak mau membandingkan dan tidak mau melihat perspektif yang lebih jauh. Allah hanya menanyakan amal kita dari tauhid yang benar. Tauhid yang benar pasti akan membuahkan amal saleh yang benar (Rais 1998, 214).

\section{Desain Kurikulum Pendidikan Islam}

\section{Berorientasi pada Ilmu Pengetahuan}

Longstreet dan Shane mendefinisikan desain kurikulum merupakan desain kurikulum yang berpusat kepada pengetahuan (the knowledge centered desain) yang dirancang berdasarkan struktur disiplin ilmu, oleh karena itu model desain ini juga dinamakan model kurikulum subjek akademis yang penekanannya diarahkan untuk pengembangan intelektual siswa (Fuaduddin dan Karya 1992, 20). Ada tiga bentuk organisisi kurikulum yang berorientasi pada disiplin ilmu, yaitu: subject centered desain, learned centered desain, problem centered desain. Setiap desain kurikukum memberikan teknik atau cara yang efektif dalam proses pembelajaran agar berjalan dengan efektif dan efisien. Tetapi tidak setiap desain kurikulum dapat dijadikan pedoman dalam melaksanakn proses pembelajaran, karena setiap desain kurikulum memiliki kelebihan dan kekurangan dalam pelaksanannya. 


\section{1) Subject Centered Curriculum}

Pada subjek ini, bahan atau isi kurikulum disusun dalam bentuk mata pelajaran yang terpisah, mata pelajaran-mata pelajaran tersebut tidak berhubungan antara satu dengan yang lainnya (Fuaduddin dan Karya 1992, 23). Organisasi bahan atau isi kurikulum pada subjek ini berpusat pada mata pelajaran secara terpisah, kurikulum ini juga dinamaka separated subject curriculum.

\section{2) Subject Correlated Curriculum}

Pada organisasi kurikulum ini mata pelajaran tidak disajikan secara terpisah, akan tetapi mata pelajaran-mata pelajaran yang memiliki kedekatan atau mata pelajaran sejenis dikelompokkan sehingga menjadi suatu bidang studi (broadfield). Mengkorelasikan bahan atau isi materi kurikulum dapat dilakukan dengan beberapa pendekatan, yaitu; 1). Pendekatan struktural, yaitu pendekatan kajian suatu pokok bahasan ditinjau dari berapa mata pelajaran sejenis. 2). Pendekatan Fungsional, yaitu pendekatan yang didasarkan pada pengkajian masalah yang berarti dalam kehidupan sehari-hari, dan 3). Pendekatan Daerah, yaitu pendekatan mata pelajaran ditentukan berdasarkan lokasi atau tempat (Muhaimin, dkk 2008, 250).

\section{3) Integreted Curriculum}

Model organisasi kurikulum ini tidak lagi menampakkan namanama mata pelajaran atau bidang studi, tetapi belajar berangkat dari suatu pokok masalah yang harus dipecahkan, selanjutnya masalah tersebut dinamakan unit. Subject Correlated Curriculum berfungsi untuk mengembangkan siswa dari segi intelektual dan seluruh aspek yang berkaitan dengan sikap, emosi, dan keterampilan. Organisasi kurikulum ini berfungsi untuk mengembangkan proses kognitif atau pengembangan kemampuan berfikir siswa melalui latihan menggunakan gagasan dan melakukan proses penelitian ilmiah (Muhaimin, dkk 2008, 257).

\section{Berorientasi pada Masyarakat}

Beauchamp merumuskan desian kurikulum yang berorientasi pada masyarakan merupakan sebuah desian kelompok social untuk 
dijadikan pengalaman belajar anak didalam kelompok. Artinya, permasalahan yang dihadapi dan dibutuhkan oleh suatu kelompok social, harus menjadi bahan kajian anak didik di sekolah. Ada tiga perspektif desain kuriukulum yang berorientasi pada kehidupan masyarakat, yaitu:

1) Perspektif Status Quo (the status quo perspective). Rancangan kurikulum ini diarahkan untuk melestarikan nilai-nilai budaya masyarakat.

2) Perspektif Pembaharuan (the reformist perspective). Kurikulum dikembangkan untuk lebih meningkatkan kwalitas masyarakat itu sendiri.

3) Perspektif Masa Depan (the futurist perspective). Perspektif ini sering dikaitkan dengan kurikulum rekonstruksi social, yang menekankan kepada proses mengembangkan hubungan antara kurikulum dan kehidupan social, politik, dan ekonomi masyarakat. Model kurikulum ini lebih mengutamakan kepentingan sosial dari pada kepentingan individu. (Muhaimin, dkk 2008, 160)

\section{Berorientasi pada Peserta Didik}

Hal yang mendasari desain ini adalah bahwa pendidikan diselenggarakan untuk membantu anak didik. Selanjutnya Muhaimin menyebutkan bahwa sebagai objek utama dalam pendidikan, terutama dalam proses belajar mengajar, peserta didik memegang peranan yang sangat dominan. Dalam proses belajar mengajar, peserta didik dapat menentukan keberhasilan belajar melalui penggunaan intelegensia, daya motorik, pengelaman, kemauan dan komitmennya yang timbul dalam diri mereka tanpa paksaan (Muhaimin, dkk 2008, 300). Jadi kurikulum harus dapat menyesuaikan dengan irama perkembangan anak didik. Dalam mendesain kurikulum yang berorientasi pada siswa perlu memperhatikan hal-hal sebagai berikut:

1) Kurikulum harus disesuaikan dengan perkembangan anak.

2) Isi kurikulum harus mencakup keterampilan, pengetahuan dan sikap yang dianggab berguna untuk masa sekarang dan 
masa yang akan datang.

3) Anak hendaknya ditempatkan sebagai subjek belajar yang berusaha untuk belajar sendiri. Artinya siswa harus didorong untuk melakukan berbagai aktivitas belajar, bukan hanya sekedar menerima informasi dari guru.

4) Diusahakan apa yang dipelajari siswa sesuai dengan minat, bakat dan tingkat perkembangan mereka. Artinya, apa yang seharusnya dupelajari bukan ditentukan dan dipandang baik dari sudut guru atau dari sudut lain akan tetapi ditentukan dari sudut anak didik itu sendiri.

\section{Konsep Tauhid Sosial}

Kata tauhid dalam agama Islam berarti taubidullah, menunggalkan atau mengesakan Allah SWT. Dalam ilmu ushuluddin, tauhid dibagi menjadi dua kategori, yaitu taubid ulubiyyah dan taubid rububiyyah. Esensi atau pokok taubid ulubiyyah adalah menyadarkan kepada kita bahwa Allah eksistensinya tunggal. Manusia mempunyai akidah, keyakinan bahwa Allah itu Maha Esa, tidak tertadingi, tidak dapat disamakan, tempat bergantung segala macam makhluk, serba sempurna, serba mahasuci, maha besar, dan lainlain, sehingga ada dua puluh sifat Allah dalam ilmu kalam (Rais 1998, 107). Lebih lanjut, Imam al-Ghazali menjelaskan Tauhid sebagai kesadaran akan pembenaran bahwa Tuhan adalah satu, mempunyai sifat dan mempunyai dzat, yang darinya segala sesuatu tercipta dengan kemahakuasaannya. Imam Ghazali juga menjelaskan untuk mengetahui kemahaesaan Tuhan dibutuhkan sembilan prinsip, yaitu bahwa Allah maha mengetahui, bahwa Allah pencipta Alam, bahwa Allah berkehendak, bahwa Allah mendengar, melihat, mengetahui, bahwa Allah berwujud, dan sebagainya (alGhazali 1999, 21-24).

Dengan pemahaman tentang tauhid yang begitu luas dan esensial tersebut, maka dalam implementasi tauhid dalam diri manusia dapat dilihat dalam kalimah syahadah yang diucapkan oleh setiap manusia. Semua itu mengandung persaksian dari lahir maupun batin. Secara tradisional dan dalam ungkapan yang 
sederhana, tauhid adalah keyakinan dan kesaksian bahwa "tidak ada Tuhan selain Allah" (al-Faruqi 1982, 9). Di samping itu, ada pengertian taubid rububiyyah, dalam arti bahwa Allah, rabb, Tuhan, yang memperhatikan, menyantuni, memberi supervisi secara sangat detail, dan teliti terhaddap segala macam makhluk yang telah diciptakan-Nya. Dengan kata lain, sesungguhnya setiap makhluk yang kelihatan ataupun tidak selama hidupnya berada dalam supervisi, dalam perhatian dan penanganan Allah SWT.

Pengawasan Allah terhadap makhluknya mengindikasikan bahwa adanya hubungan antara ketauhidan dan pola kehidupan makhluknya. Dalam artian bahwa hubungan antara iman dan amal diantara Allah dan makhluknya, iman dan amal atau akidah dan muamalah keduanya berhubungan dengan yang lain, ibarat sebuah pohon atau hubungan musabab dengan sebab dan kesimpulan dengan pendahuluan (Sabiq 1996, 31). Kaitan iman dan amal yang secara falsafi merupakan integritas yang utuh, melandasi bahwa ketauhidan tidak melepaskan dimensi perbuatan makhluk-Nya.

Lebih lanjut dalam dimensi kemanusiaan bahwa pola hubungan ketauhidan dan sosial ibarat sebuah hubungan antara budi dan perangai (al-Ghazali 1986, 175). Apabila seseorang telah beriman dan menyatakan bahwa Allah adalah Tuhannya, maka secara khusus ia meluruskan tindakannya untuk mencari Ridho Tuhannya. Sehingga dari hal tersebut, tergambar dengan jelas bahwa rumusan tauhid sosial secara eksplisit merupakan rumusan antara keimanan dan perilaku amaliahnya.

Rumusan tauhid sosial dalam pandangan Amien Rais dirumuskan dengan tauhid sosial adalah dimensi sosial dari taubidullah. Ini dimaksudkan agar taubid ulubiyyah dan tauhid rububiyyah yang sudah tertanam di kepala kita, bisa diturunkan lagi ke dalam dataran pergaulan sosial, realitas sosial, secara konkret (Rais 1998, 108). Jadi, secara singkatnya, yang dimaksud dengan tauhid sosial yaitu nilai-nilai tauhid yang diterapkan ke dalam kehidupan sehari-hari.

Tauhid yang dalam nalar umat muslim dipahami sebagai keilmuan yang tinggi, namun jika dikonsepsikan dengan sosial maka 
tauhid menjadi keilmuan yang universal dan menaruh perhatian dalam dimensi kemanusiaan. Sebab tauhid sosial memberi makna, arah, dan tujuan, pada dimensi kemanusiaan. Ia juga merupakan sumber kesatuan dimensi kemanusiaan, serta sebagai klaim kesatuan antar ilmu-ilmu yang lainnya (Rais 1998, 244). Tauhid tidak hanya dilihat sebagai keesaan Tuhan dan kuasa-Nya, melainkan dilihat sebagai manifestasi Tuhan di dunia, yang mencakup semua bidang, baik sosial, keilmuan, sains, agama, dan sebagainya.

Korelasi tauhid dengan keduniawian tersebut mempunyai benang merah dari ajaran Islam yaitu keadilan. Karena Islam itu merupakan religion of justice, maka secara potensial setiap orang Islam bisa menjadi trouble maker bagi kemapanan yang tidak adil. Maka dengan menerapkan konsepsi tauhid sosial dalam menjalani kehidupan bermasyarakat, berbangsa, dan bernegara, yang tidak terlepas dari kepentingan politik, ekonomi, bisnis, budaya dan sebagainya, umat Islam akan menemukan cirinya yang murni.

Sebab ciri Islam sebagai tauhid adalah agama yang menempatkan manusia sebagaai makhluk yang berharga diri (berkepribadian), atas tanggung jawabnya ia memperoleh kebebasan, keadilan, dan tidak membenarkan diskriminasi antara sesama manusia, serta diberi keleluasaan untuk memperkembangkan hidup dalam rangka mempertinggi martabat umat manusia (Basyir 1995, 9). Islam memandang manusia mempunyai keistimewaan untuk memakmurkaan dunia, sehingga manusia diberi akal dan kualitas untuk membangun peradaban tauhidullah dengan menggunakan seperangkat dimensi yang ada di dunia.

Peradaban Islam telah menunjukkan integrasi antara tauhid dan sosial, dimana konsep-konsep yang turun dalam bentuk ayat-ayat al-Quran diturunkan secara gradual. Periode pertama (periode Makkah-1) berkenaan dengan konsep tahuhid, penciptaan, hari akhir, etika, dan tentang alam. Periode kedua (periode Makkah-2) berkaitan dengan konsep ibadah, din, ilmu, kenabian, dll. Periode ketiga (periode Madinah) meliputi konsep ukhuwah, ummah, jihad, 
daulah, dan lain-lain. Dari konsep-konsep itulah kemudian Islam membangun peradabannya. Munculnya komunitas ahlu Suffah di madinah adalah merupakan contoh betapa para sahabat memahami konsep-konsep itu secara mendalam, dan dari merekalah tradisi keilmuan Islam berkembang yang kemudian membentuk peradaban unggul di masa setelahnya.

Keunggulan umat Islam dengan menerapkan prinsip-prinsip tauhid dan dimensi masyarakat tersebut, telah melahirkan konsep integritas antara tauhid dan sosial, yang dalam keilmuan sekarang dipahami sebagai tauhid sosial. Kiranya pernyataan dari Amin Abdullah menjadi relevan, ia mengatakan bahwa:

"Tanpa dialog dengan realitas maka pemahaman keberagamaan (ketauhidan) akan cenderung mengarah ke kontemplasi, sehingga kurang bermuatan etika yang terkait langsung dengan pembentukan perilaku individu dalam kehidupan di dunia serta kepeduliannya terhadap sosial". (Abdullah 1995, 235-236)

Tauhid sosial dengan membawa visi dan misi yang unggul seperti di atas, membumikan ajaran tauhid agar terintegrasi dengan realitas sosial, hal itu mengingatkan kepada kita bahwa erat kaitannya dengan kewajiban dan tugas sebagai seorang Muslim yaitu seperti yang termaktub dalam al-Qur'an bahwa selain beribadah, manusia dituntut untuk berilmu, beriman dan bertakwa.

Kaitan antara ketakwaan dan tauhid sosial disini terletak pada kualitas manusia untuk menerapkannya di dalam dunia, atau dalam konsepsinya Muhammad Iqbal adalah manusia yang mukmin dan bertakwa dengan menyadari dirinya sebagai penyambung Tuhan (Iqbal 2002, 203). Dunia harus dikendalikan oleh orang yang bertauhid dan bertakwa sebab dengan kedua hal tersebut dimensi sosial dapat diterjemahkan dengan baik, dan tentu akan menjadi dunia yang adil dan makmur secara merata karena pengelolaan dunia akan dituntun oleh nilai yang diajarkan Allah SWT (Iqbal 2002, 28-29). Oleh karena itu, dimensi sosial harus dilaksanakan oleh umat Islam dengan kemampuannya mengaplikasikan konsepsi Tauhid yang berwawasan sosial. Dengan demikian manusia sebagai pelaku dari tindakan moral, karenanya harus mampu mengubah dirinya, sesamanya atau masyarakatnya, alam dan lingkungannya, 
untuk bisa mengaktualisasikan pola atau perintah Ilahi, dalam dirinya sendiri dan juga dalam diri mereka semuanya itu (al-Faruqi 1982, 12). Karena dengan mentransformasikan dirinya kepada keadaan yang melebur dengan segala elemen dunia, maka akan mewujudkan visi dan misi tauhid yang ada di dalam diri manusia.

\section{Aktualisasi Konsep Tauhid Sosial dalam Kurikulum Pendidikan Islam}

Pendidikan agama Islam sebagai institusi kependidikan yang menjembatani ajaran-ajaran Islam untuk dapat dijadikan sebagai pegangan hidup melalui pendidikan, memerlukan upaya untuk dikembangkan kearah yang berkelanjutan. Agar dalam pelaksanaan proses pembelajarannya tidak mengalami ketimpangan dan jurang pemisah antara realitas sekarang dengan materi-materi yang diajarkan di dalamnya. Upaya untuk mengembangkan kurikulum Pendidikan Islam terutama dikhususkan dalam jenjang SMA. Hal ini disebabkan karena kebutuhan akan perilaku dan kontekstasi lebih besar di jenjang tersebut. Jenjang SMA memerlukan kurikulum yang mampu membentuk kecakapan hidup untuk dijadikan sebagai tolak ukur berkehidupan selepas lulus dari sekolah.

Pengembangan kurikulum Pendidikan Islam di SMA sesuai dengan Peraturan Menteri Pendidikan Nasional nomor 22 tahun 2006. Dalam Peraturan Menteri (Permen) tersebut disebutkan bahwa pengorganisasian kelas-kelas pada SMA/MA dibagi ke dalam dua kelompok, yaitu kelas $\mathrm{X}$ merupakan program umum yang diikuti oleh seluruh peserta didik, dan kelas XI, XII merupakan penjurusan yang terdiri atas empat program; IPA, IPS, Bahasa, Keagamaan khusus untuk MA (Muhaimin, dkk 2008, 348). Sistem penjurusan menjadi ciri khas dari adanya jenjang SMA. Kemudian dalam pengembangan kurikulumnya agar sesuai dengan konsepsi dan praktik pendidikan di lapangan, maka jenjang SMA diberikan kecakapan untuk dapat menguasai materi-materi yang dapat dijadikan kecakapan dalam bekerja serta berkepribadian ihsani, khususnya dalam pendidikan agama Islam. 
Dalan konteks sosial-kultur pendidikan Islam harus tidak melepaskan diri dengan adanya perkembangan-perkembangan yang ada di dunia ini. Materi-materi yang ada di dalam kurikulum pendidikan agam Islam harus mencerminkan keislamannya sekaligus memanifestasikannya dalam pergulatan sosial yang sedang menggejala. Kurikulum pendidikan agama Islam mempunyai konsen dalam hal ketauhidan, sehingga antara realitas transendental harus di ikutkan dalam realitas sosial. Hal ini merupakan langkah untuk menjadikan Pendidikan Islam sebagai basis pendidikan bagi umat Islam, yang membedakannya dengan pendidikan umum yang cenderung sekuler.

Dengan demikian maka diperlukan formulasi pola pengembangan dari konsepsi tauhid sosial seperti yang sudah dijelaskan pada bab sebelumnya. Konsepsi tauhid sosial dapat dijadikan muatan isi dari pengembangan kurikulum Pendidikan Islam di SMA, khususnya. Sebab dengan adanya tauhid sosial yang menjadi paradigma pengembangannya, maka diharapkan pola pengembangan lebih berorientasi kepada pembentukan kurikulum yang mencakup kecakapan dalam hidup dengan segala realitas, serta tidak melepaskan ajaran keyakinan tauhid.

\section{Pola Pengembangan Kurikulum Pendidikan Islam SMA}

Pola pengembangan kurikulum Pendidikan Islam di SMA harus sudah disesuaikan dengan pengalaman belajar artinya disinergikan antara pendidikan dan pengalaman sosial. Pola pengembangan kurikulum Pendidikan Islam di SMA yang dikonsepsikan dengan tauhid sosial, lebih diorientasikan kepada kesatuan antara tauhid dengan realitas yang terjadi di masyarakat. Sebagaimana yang dijelaskan oleh Ismail Raji’ al-Faruqi,

"Tidak ada harapan akan kebangkitan yang sungguh-sungguh dari ummah, kecuali sistem pendidikan dirubah dan kesalahan-kesalahannya diperbaiki. Sesungguhnya yang diperlukan bagi sistem itu adalah dibangunnya bentuk baru... sistem ini jangan samPI dijadikan sebagai keuntungan pragmatis, ekonomi, materiil semata, atau hanya dijadikan sebagai pelanjut ideologis semata, melainkan harus terintegrasi secara isi”. (al-Faruqi 1982, 21-22) 
Pengakuan al-Faruqi terhadap keberhasilan sebuah ummat didasarkan atas terjalinnya sistem pendidikan yang bernuansa integralistik. Dalam artian vision Islam dan semangat zaman dijadikan satu atap dalam bentuk isi kurikulumnya. Hal itu, bertujuan agar lulusan-lulusan sekolah menengah berperilaku sesuai dengan ajaran agama, berpartisipasi dalam kehidupan bermasyarakat dan bernegara, bertanggung jawab, mengembangkan diri secara kreatif dan inovatif, dan sebagainya (Mulyasa 2009, 28). Dengan mengacu kepada tujuan yang hendak dicapai tersebut, maka pengembangan kurikulum di SMA dengan menggunakan kerangka konseptual tauhid sosial, akan berdampak kepada pembentukan jati diri seorang peserta didik yang tanggap dalam permasalahan dan juga cakap dalam religius.

Tauhid harus dipahami sebagai individuasi Allah sebagai sentral pemahaman pengetahuan umat Islam (Al-Attas 2006, 83). Sehingga pengetahuan tentang ketauhidan Tuhan dapat dijadikan pijakan untuk memahami segala realitas yang ada. Sebab proses inviduasi Tuhan merupakan manifestasi dari keabsolutan Allah dalam semua tingkatan wujud (Al-Attas 2006, 87). Dari sini dapat dipahami proses kesatuan Allah itu tersendiri, namun manifestasi terhadap alam semesta dan segala ciptaaan merupakan realitas dan dimensi yang masih di bawah pengawasan-Nya.

Dari program kurikulum tersebut disebabkan oleh kemendesakan masyarakat untuk mengambil alih kehidupan dari golongan sekuler. Sebagaimana yang dikatakan oleh al-Faruqi bahwa ummat Islam sedang terjangkit penyakit kemandekan dalam bidang ekonomi, politik, pendidikan, religio-kulture, dan sebagainya (al-Faruqi 1982, 5). Hal ini harus dihadapi oleh umat agar dalam kehidupannya dapat bersatu untuk membangun kembali tatanan umat Islam yang rahmatan lil 'alamin. Sehingga apa yang dirumuskan oleh dia, memerlukan pentingnya penekanan aspek pendidikan sebagai kelanjutan pembentukan wawasan umat, serta pelanjut tongkat estafet tugas khalifatullah manusia di bumi ini. 


\section{Desain Kurikulum}

Di dalam desain kurikulum Pendidikan Agama Islam yang dikemukakan oleh para pakar kurikulum, memiliki tiga macam desain. Seperti yang dikatakan Rusman dalam buku Manajemen Pengembangan Kurikulum, dikutip dari buku Kurikulum dan Pembelajaran Pendidikan Agama Islam karangan Heri Gunawan, menyebutkan beberapa desain pengembangan kurikulum, sebagai hasil kajian dari beberapa sumber (Gunawan 2013, 47). Diantaranya desain kurikulum yang (1) berorientasi pada disiplin ilmu, (2) berorientasi pada masyarakat, dan (3) berorientasi pada peserta didik.

\section{Desain Kurikulum Berorientasi pada Disiplin Ilmu}

Pengembangan desain kurikulum yang berorientasi pada disiplin ilmu ini merupakan awal dari sebuah asumsi, bahwa fungsi sekolah pada dasarnya untuk mengembangkan kemampuan berpikir peserta didik. Seperti pendekatan di dalam pengembangan kurikulum, yaitu pendekatan subjek akademis. Dimana pengembangan kurikulum dilakukan dengan cara menetapkan terlebih dahulu mata pelajaran apa yang harus dipelajari oleh peserta didik, yang diperlukan untuk (persiapan) pengembangan disiplin ilmu (Muhaimin, dkk 2008, 140). Pendidikan Islam di SMA meliputi aspek Al-Qur'an/Hadis, keimanan, akhlak, ibadah/muamalah, dan tarikh/ sejarah umat Islam. Ilmu pengetahuan yang disusun oleh para ahli dalam berbagai disiplin ilmu diajarkan di sekolah dalam bentuk mata pelajaran dengan berorientasi kepada pembentukan manusia yang mempunyai wawasan keislaman yang berlandaskan tauhid dan ibadah. Garis besar kurikulum yang hendak dicapai dalam tauhid sosial diantaranya adalah:

1) Adanya relevansi dengan tujuan pendidikan Islam, yaitu upaya dalam rangka ibadah kepada Allah SW'T

2) Disesuaikan dengan tingkat perkembangan dan usia anak didik

3) Adanya penyusunan kurikulum yang integral 
4) Materi yang disusun memiliki relevansi dengan masalahmasalah yang mutakhir, yang sedang dibicarakan.

5) Mempunyai pengaruh positif dan pragmatis

6) Memerhatikan kejuruan untuk mencari penghidupan dan adanya ilmu alat untuk mempelajari ilmu-ilmu lain. (Hamid 2012, 221-222)

\section{Desain Kurikulum yang Berorientasi pada Masyarakat}

Asumsi yang mendasari bentuk dari desain kurikulum ini adalah, bahwa tujuan dari sekolah adalah untuk melayani kebutuhan masyarakat. Karena, kurikulum pada dasarnya adalah jawaban atas berbagai kebutuhan masyarakat akan pendidikan. Oleh karena itu, kebutuhan masyarakat harus dijadikan dasar dalam mendesain isi kurikulum (Gunawan 2013, 48). Ada beberapa ahli yang merumuskan kurikulum sebagai sebuah desain kelompok sosial untuk dijadikan pengalaman belajar bagi peserta didik di sekolah. Artinya, permasalahan yang dihadapi dan dibutuhkan oleh kelompok sosial, harus menjadi bahan kajian peserta didik di sekolah, dengan cara menganalisis permasalahan yang ada dan sedang terjadi.

Belajar melalui pemecahan masalah seperti itu, diharapkan perkembangan peserta didik tidak hanya terjadi pada segi intelektual saja, melainkan seluruh aspek seperti sikap, emosi, atau keterampilan. Desain kurikulum yang berorientasikan pada masyarakat ini, mengandung muatan bahwa peserta didik adalah makhluk sosial yang mana dia akan terjun ke dalam masyarakat, dan maka dari itu, peserta didik harus mempersiapkan terlebih dulu bekal untuk menjadi bagian dari masyarakat.

\section{Desain Kurikulum Berorientasi pada Peserta Didik}

Pendidikan yang diselenggarakan adalah untuk memenuhi atau membantu anak didik, merupakan asumsi yang mendasari desain ini. Anak didik merupakan manusia yang sangat unik. Mereka memiliki karakteristik tertentu. Bahwa anak adalah makhluk yang sedang berkembang, yang memiliki minat dan bakat yang beragam. 
Kurikulum harus dapat menyesuaikan dengan irama perkembangan yang dialami oleh peserta didik (Gunawan 2013, 51).

Sebagaimana yang ada di dalam ajaran Islam yang menekankan kepada pendidikan yang dimulai dari dalam kandungan samPI akhir hayat. Anak didik dilihat sebagai manusia yang masih kosong tanpa noda (Tabula rasa), atau mereka sudah mempunyai potensi-potensi untuk dimunculkan. Hal ini tanpa ikut campur pendidikan, maka tidak akan dapat dilihat keberhasilannya. Kurikulum dapat dijadikan sebagai pengembangan kemampuan peserta didik untuk membuka potensi-potensi yang sudah. Namun harus memperhatikan kondisi dari anak didiknya.

Kiranya yang perlu diperhatika dalam pengembangan kurikulum adalah prinsip-prinsip pembelajaran yang dikemukakan oleh UNESCO. Empat pilar pendidikan (learning to know, learning to do, learning live together, dan learning to be) harus dimiliki oleh para penyusun kurikulum (Mudhafir 2011, 43). Sebab dari empat pilar tersebut sebenarnya mempunyai signifikansi dengan ajaran Isalam yang termuat dalam al-Qur'an, yaitu amal dan iman yang menjadi landasan bagi terbentuknya manusia yang berpendidikan.

Desain kurikulum yang mengacu pada peserta didik diharapkan mampu untuk membentuk peserta didik berkeprbadian yang sesuai dengan jenjang dan kegunaannya. Sebagaimana yang ada dalam Pendidikan Islam di SMA, peserta didik harus dijadikan sebagai alat untuk meembentuk dirinya dan juga pendidikan itu sendiri. Dengan begitu kurikulum pendidikan di tingkat SMA disesuaikan dengan usia anak didik, dan juga selaras dengan fitrah manusia (Majid 2004, 78). Pengembangan kurikulum di SMA menuntut adanya pandangan terhadap anak didik, bahwa mereka sebagai seorang individu yang seang berkembang untuk mencaPI sebuah kematangann, maka diperlukan penyesuaian dengan segala yang berkaitan dengan dirinya. Agar dalam membentuk kompetensi diantara anak didik melalui proses pembelajaran dapat dilakukan dengan selaras dan tanpa hambatan. 


\section{Isi Kurikulum Pendidikan Islam SMA}

Kurikulum Pendidikan Islam di SMA mempunyai kedudukan yang strategis untuk mencapai tujuan pendidikan nasional, sejajar dengan mata pelajaran lainnya. Keberadaan Pendidikan Islam di SMA penting dalam sistem pendidikan nasional. Sebab tujuannya untuk mengembangkan, mengamalkan, menghayati, dan mengamalkan nilai-nilai agama yang menyerasikan antara ilmu pengetahuan, seni, dan tekhnologi (Rahardo 2010, 67). Kurikulum Pendidikan Islam yang mempunyai peran dan posisi yang sama di jenjang SMA, mengharuskan para perumus untuk mengetahui segala aspek yang harus dipenuhi dalam pengembangan kurikuumnya.

Salah satu yang penting adalah isi dari kurikulum itu sendiri. Tugas dari guru dan para penyusun kurikulum Pendidikan Islam di SMA adalah mengembangkan fitrah agar menjadi kemampuan aktual, dan mengarahkannya kepada kebikan, sehingga peserta didik dapat mencaPI kesempurnaan dalam arti kelengkapan kemanusiaan yang sesungguh-sungguhnya (Natsir 1976, 82, bandingkan dengan Shihab 1997, 283). Kesempurnaan kemanusiaan yang menjadi tiik tolak bagi pengembangan kurikulum Pendidikan Islam di SMA, yang mana tidak hanya ranah keduniawian belaka, melainkan kompleksitas pemahaman harus ada di dalamnya. Mulai dari pegetahuan teoritis, akidah, akhlak, muamalah, an sebagai harus ada dalam kurikulum Pendidikan Islam di SMA. Agar anak didik bisa mengembangkan potensinya menuju kearah perbaikan dan pemenuhan kehidupan.

Dengan demikian urgensi dari dari isi kurikulum Pendidikan Islam yang dikembangkan akan menemukan titik pangkalnya dalam filosofi pendidikan. Sebagaimana dinyatakan oleh Tasman Hamami bahwa sebenarnya tujuan Pendidikan Islam merupakan seberkas refleksi dari pemikiran filosofis seperti esensialisme, perenialisme, progresifisme, dan rekonstruksionisme (Tasman 2006, 204). Jika ditelaah lebih lanjut maka gagasan yang ada dalam perumusan kurikulum sesuai dengan kedua pemikir (Faruqi dan Amin) yang penulis kaji. Isi kurikulum dan tujuan kurikulum termasuk ke dalam 
filsafat pendidikan progresifisme. Dalam pemikiran progresifisme pendidikan didasarkan pada kebutuhan peserta didik secara realistis dan integratif antar seluruh aspek.

\section{Catatan Akhir}

Kurikulum pendidikan Islam harus berkembang sesuai dengan zaman. Agar dalam merealisasikan ajaran-ajaran Islam tidak terjebak di dalam romantisme ortodokisme amupun historisisme. Untuk itu diperlukan sebuah formula yang tepat, salah satunya melalui konsep tauhid sosial. Tauhid sosial di dalam ranah pendidikan Islam sesuai dengan yang dicita-citakan oleh Ismail Raji' al-Faruqi yaitu untuk membentuk benteng pertahanan umat Muslim dari tantangan zaman global. Adapun terkait dengan desain yang akan dijadikan pedoman dalam pelaksanaan pembelajaran, maka mengacu pada tiga ranah yaitu, desain yang berorientasi pada ilmu pengetahuan, desain yang berorientasi pada masyarakat, dan desain yang berorientasi pada peserta didik.

Desain yang berorientasi ilmu pengetahuan, kurikulum yang akan dibentuk lebih banyak memadukan antara sumber ajaran Islam dengan ilmu pengetahuan. Desain masyarakat dan peserta didik bisa membentuk jati diri umat Muslim yaitu perpaduan antara kesalehan individual dengan kesalehan sosial. Dengan mengacu pada desain tersebut, muatan kurikulum pendidikan Islam bisa menjadikan peserta didik tidak hanya menguasai materi-materi yang bersumber pada penguasaan keislaman semata, melainkan materi tersebut dapat dipahami secara kontekstual pada ranah kehidupan sosial.

Konsep tauhid sosial dalam pengembangan kurikulum Pendidikan Islam khususnya di SMA, bertujuan untuk menumbuhkan kesadaran sosial yang tinggi pada peserta didik SMA. Tauhid sosial sendiri dapat diartikan sebagai bentuk kesadaran umat Islam yang dilandasi dengan nilai-nilai tauhid dalam berkiprah di dalam realitas sosial. Tauhid sosial dalam konseptualisasinya mempunyai beberapa prinsip, diantaranya; sejarah, pengetahuan, metafisika, etika, tata sosial, keluarga, tata 
politik, tata ekonomi, tata dunia, dan estetika. Semua prinsipprinsip tersebutlah yang melandasi terbentuknya tauhid sosial di dalam kurikulum Pendidikan Islam di SMA. Tujuan dengan diberlakukannya kurikulum tauhid sosial di SMA kiranya sebagai kesadaran ummat Islam yang dilandasi ketauhidan dalam membentuk kehidupan di dalam dunia sosial. Isi dari tujuan tersebut tidak hanya mencakup nilai-nilai tauhid semata, melainkan problem-problem yang terjadi di realitas sekarang. Yang kemudian dievaluasi keberhasilan maupun prestasi yang hendak dicapai oleh masing-masing pihak yang terlibat di dalamnya.

\section{Daftar Pustaka}

Abdullah, M. Amin. 1995. Falsafah Kalam di Era Postmodernisme. Yogyakarta: Pustaka Pelajar.

Ahmadi, Abu, dan Nur Uhbiyati. 2001. Ilmu Pendidikan. Jakarta: Rineka Cipta.

Al-Attas, Fajri. 2006. Sungai tak Bermuara, Risalab Konsep Ilmu dalam Islam Sebuah Tinjauan Ihsani. Jakarta: Diwan Publishing.

Basyir, H.A. Azhar. 1995. Pendidikan Agama Islam (Aqidab). Yogyakarta: Perpustakaan Fakultas Hukum Universitas Islam Indonesia.

Daradjat, dkk., Zakiyah. 2011. Ilmu Pendidikan Islam. Jakarta: Bumi Aksara.

Faruqi, Ismail Raji’ al-. 1982. Taubid. Diterjemahkan oleh Rahmani Astuti. Bandung: Pustaka.

Fuaduddin, dan Karya. 1992. Pengembangan dan Inovasi Kurikulum. Jakarta: Dirjen Bimbaga Islam dan Universitas Terbuka.

Ghazali, Abu Hamid Muhammad al-. 1986. Akidah Muslim. Diterjemahkan oleh Majyudin Syaf. Jakarta: Pedoman Ilmu Jaya.

— 1999. Taubidullah Risalah Suci Hujjatul Islam. Diterjemahkan oleh Wasmukan. Surabaya: Risalah Gusti.

Gunawan, Heri. 2013. Kurikulum dan Pembelajaran Pendidikan Agama Islam. Bandung: Alfabeta. 
Hamid. 2012. Pengembangan Kurikulum Pendidikan. Bandung: Pustaka Setia.

Iqbal, Muhammad. 2002. Rekonstruksi Pemikiran Agama dalam Islam. Yogyakarta: Jalasutra.

Majid, Abdul. 2004. Pendidikan Agama Islam Berbasis Kompetensi: Konsep dan Implementasi Kurikulum 2004. Bandung: Remaja Rosda Karya.

Mudhafir, Ali. 2011. Aplikasi Pengembangan Kurikulum Tingkat Satuan Pendidikan dan Bahan Ajar dalam Penddikan Agama Islam. Jakarta: Raja Grafindo Persada.

Muhaimin, dkk. 2008. Pengembangan Model Kurikulum Tingkat Satuan

Dasar pada Sekolah dan Madrasah. Jakarta: RajaGrafindo Persada.

Mulyasa, E. 2009. Kurikulum yang Disempurnakan, Pengembangan Standar Kompetensi dan Kompetensi Dasar. Bandung: Remaja Rosda Karya.

Natsir, M. 1976. Kapita Selekta. Jakarta: Bulan Bintang.

Rahardo, Rahmat. 2010. Inovasi Kurikulum Pendidikan Agama Islam:

Pengembangan Kurikulum dan Pembelajaran. Yogyakarta: Magnum Pustaka.

Rais, M. Amin. 1998. Taubid Sosial: Formula Menggempur Kesenjangan. Bandung: Mizan.

Sabiq, Sayyid. 1996. Akidah Islam, Suatu Kajian yang Memposisikan Akal Sebagai Mitra Wabyu. Diterjemahkan oleh Sahid HM. Surabaya: Al-Ikhlas.

Shihab, M. Quraish. 1997. Wawasan al-Qur'an. Bandung: Mizan.

Tasman, Hamami. 2006. "Pemikiran Pendidikan Islam: Telaah tentang Kurikulum Pendidikan Agama Islam di Sekolah Umum.” Disertasi, Yogyakarta: Program Pascasarjana UIN Sunan Kalijaga. 